\title{
Model of Slum Settlement Policy in East Lombok, West Nusa Tenggara
}

\author{
* Nurul Matinni ${ }^{1)}$ and Armansyah ${ }^{2)}$
}

1) Master Program Student of Geography Education Faculty of Social Science, Universitas Negeri Padang, INDONESIA

2) Faculty of Agricultural, Andalas University, Indonesia

Email: nurulmatinni22@gmail.com

*Corresponding Author, Received: February 17, 2018, Revised: April 25, 2018, Accepted: May 24, 2018

\begin{abstract}
This research is purposed to formulate model of slum settlement policy in Nusa Tenggara Barat Province. Method used in this study is mixed method with data collection method is Purposive Sampling and Analytical Hierarchy Process (AHP). Study discussion is resulting in alternative policy of settlement policy in Nusa Tenggara Barat Province, Indonesia that is: (1) demolition of slum area; (2) opening job vacancy; (3) providing low-cost housing; (4) providing loans from banks; and (5) flats. From these alternative policies, it is aimed to raise standard of living in Nusa Tenggara Barat province, especially in the area of study and eliminating slums area to achieve the correct urban planning.
\end{abstract}

Keywords: Policy, Slum Area, Settlement

\section{Introduction}

Tourism development is an important strategy as an effort to improve economic development in a region. The development of tourism will give an impact on the progress of tourism industry and increase employment opportunities (Zhang, 2013). Natural tourism activities can improve the economy of informal sector, as well as the community economy around tourist area (Hadi, 1994; Hermon, 2012a; Hermon, 2012b; Hermon, 2014a; Hermon, 2014b). Recreational activities in addition to give an attraction for tourists, it will also affect the community around tourist area. Usually, the community will take advantage of these tourist activities to earn a living. Various professions can be created by people around tourist area such as trade, farm and agriculture.

The tourism sector as an economic activity has become a potential mainstay and development priority for many countries, especially developing countries such as Indonesia which has a wide area potential and considerable tourist attraction, a lots of natural beauty, various cultural heritage and community life. Tourism in Indonesia is one of economy supporter that has a bright prospect, but until now its role is still invisible in line with expectations of Indonesia's development. But in reality there are still a lot of people live in infeasible houses in the area of halal tourism at east Lombok regency. The formation of slum housing are entity of housing and settlement units that suffer from quality degradation, highly populated, irregular and does not meet the requirements and conditions of facilities and infrastructure which are set in planning and urban development.

From 1.2 million people in East Lombok today, the number of poor people in macro is 222,019 people. In addition to macroeconomic poverty, the Central Bureau of Statistics in 2015 also recorded micro poverty data. The discrepancy between macro poverty data and micro data is big. The number of micro poverty data was 473,836 people. This micro poverty data is more detailed and the indicators are not only in terms of consumption. Its indicator variable is not from consumption only but also from the condition of housing and 
other factors. Data from Central Bureau of Statistics (BPS) noted that the number of poor people in Nusa Tenggara Barat is $16.08 \%$ from total population in West Nusa Tenggara. Poverty is the causal factor of many housing problems and slum area.

Based on national data from Central Bureau of Statistics in 2015 (BPS), the number of infeasible housing was 7.6 million units. East Lombok Regency is the largest contributor to the number of uninhabitable houses throughout Indonesia. Meanwhile, the number of citizens who did not have a feasible housing in East Lombok Regency was 286 thousand units. The housing condition in East Lombok Regency from 177.88 Hectares of Urban Area is categorized as Heavy Slum. It is spread across 16 villages and sub-districts that located in Labuhan Haji regency, Selong sub-district, Terara, Masbagik and Sakra. In addition to the heavy slum, there are also other slums where the condition of roof and wall do not meet standard and also roads do not meet the environmental standard of 1.5 meters (Directorate housing of east Lombok). Evanatha Organization (2003) said that slum dwellers had been established for many years. These slum dweller faced problem of land ownership, educational level, economic pattern and other problems. Slum areas were developed from early 1980s to early 1990s and Urban Development had become one of the main target areas in government's development agenda.

Slums are a dense area where many populations are live in poor neighborhoods with densely populated housing and unhygienic environments, inadequate infrastructure, poor sanitation and drinking water facilities. Settling in slums has a direct impact on public health (Goswami and Manna, 2010). According to UNHABITAT 2002, slum was over populated settlements which characterized by ineligible basic service standard. These slums are often not recognized and handled by public authorities as an integral part of the city. Further, slum coverage includes low-income settlements and undesirable settlements. In slum housing there was a group of individuals who lived together under one roof with difficult access to water, poor sanitation; structural quality or building were decrepit, overcrowded space, and unclear land ownership. There are two reasons for the formation of slum settlements. There are internal factors and external factors. Internal factors include lack of collateral assets; lack of saving and other financial asset such as daily worker or having a low income job. External factors were such as land price and expensive housing. The scope of society's role in improving quality is very important. Community's role is still very low in actively participating in discussions about development planning of slum housing and slum settlements, in providing support for the implementation of slum housing and slum settlement plan in nearest locations in accordance with their authority and low awareness in maintaining housing facilities that have been provided by government. In the era of development, people's housing development efforts received great attention from various governmental agencies as an effort to realize one of the community's basic needs. The purpose of this study is to determine the level of slum housing in the area of halal tourism in eastern Lombok regency and determine the direction of slum settlement policy in the area of halal tourism in eastern Lombok regency.

\section{Method}

Study location is in Nusa Tenggara Barat province. The scope of research area is Labuhan Haji, East Lombok, Sungkun, Ekas Buana, Jerowaru, Pemongkong, Jerowaru, and Sambelia districts and East Lombok regency. Study period was in July 2017. This study conducted in several steps, which were preparation, field observation, and primary and secondary data collection. Observation in coastal tourism area at Labuhan Haji, Kura-Kura and Sambelia districts become was a study focus. Sampling was determined by Purposive sampling technique. Data analysis technique used Analytical Hierarchy Process (AHP) (Hermon, 2009; Hermon, 2015; Hermon, 2016a; Hermon, 2016b; Hermon et al., 2017). The application of Analytical Hierarchy Process (AHP) is to select alternatives or to set alternative priorities from slum settlement policy models in East Lombok, West Nusa Tenggara (Hermon, 2017).

\section{Results and Discussion}

Although Lombok is experiencing economic growth as a contribution from halal tourism, but there are still many gaps that occur in the area of halal tourism. Based on research in west Nusa Tenggara there are still many slum settlements, 3 of them are on coastal area of Labuhan Haji, Kura-Kura and Sambelia Districts. 
The gap between rich and poor is still widening. Economic growth is not reach tourist area. Factors that are causing these slums to be developed are low income and day worker. In addition, they do not have an ownership for their housing. In tourist area in Labuhan Haji, population that occupies the slum is mostly non-indigenous. Mostly, man work as fishermen and his wife sell grilled fish at peripheral of tourist area. The density of this housing is very high. There is too much mud on the road. And mostly do not have water duct and poor drainage. Trash is dumped in front of the house and many piles of unused timbers. The following is parameter for slum's housing assessment: 1) housing condition, 2) type of house, 3) building density, 4) education, 5) hygiene, 6) habitual of population, 7) customs, 8) family Income, 9) work status, 10) access to clean water, 11) toilet facility (MCK), 12) garbage management, 13) wastewater duct, 14) drainage, 15) environmental road, 16) flood frequency, 17) lighting and communication, 18) green area (Standard of Director General of Settlements on 2006).

Alongside Kura-Kura beach tourist area, it is lined housing that infeasible for habitation where it is built from bamboo. But closer to tourist area, there is a significant change where housing is permanent and eligible for habitation because government program has been running in this area to arrange the tourist area. It is also supported by the type of resident's livelihoods in this tourist area. Type of occupation in closer area is mostly as tobacco farmer and type of works for productive age are security guard and cafe waitress. In this tourist area many foreign investors built villas and cafes. So even though the government does not arranging residential housing here, individual or private company can take initiative to develop good settlement because of its potential income. In Sambelia district, there is also slum settlement. This area lies on Rinjani mountainside. The density of housing is not too crowded but many houses is not habitable in this tourist area. Along the way we can observe some of government programs that have been implemented, but not all of them. Here also there are areas that frequently affected by long drought so that at certain times farmers get water shortage that causing fluctuations in farmers' incomes. From the results of data processing field using standard parameters of housing assessment Standard Director General of Human Settlements (2006) obtained results as shown below.

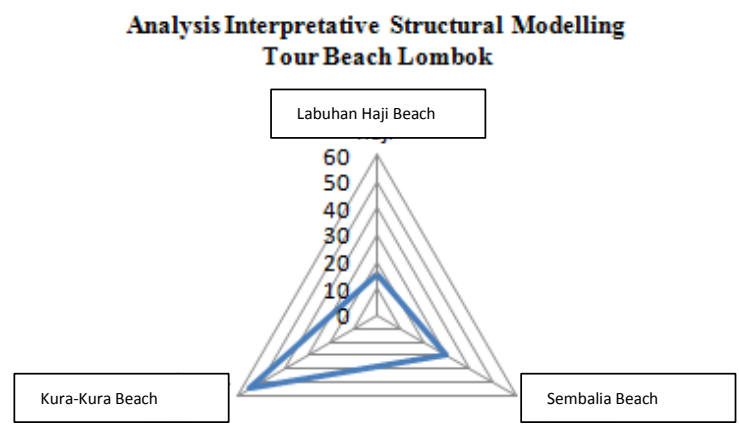

Figure 1. Analysis Interpretative Structural Modelling Tour Beach Lombok

Kura-Kura beach access is categorized well enough so that the level of economic people around the beach is in good category, many investors are planting stock there so open job vacancy for the community. The naked beach is categorized under the Sembalia beach although its access is good but the economy around the tourism area is not developed and the slum housing level there is quite a lot whereas the beach Labuhan Haji is the lowest level of its economy, the housing in this region many in slum category and this influence tourist destinations so that the income is low. It is observed that many uninhabitable housing in West Nusa Tenggara province, especially in these three areas. There are some government programs that are running where it can be seen from changes in the area of Kura-Kura beach tourism area. Also found in this study, residents that occupy small rent-houses with a small family member that is not habitable in Labuhan Haji coastal area. In addition, there is also housing without land ownership where member of people in the house are plenty.

This also happened in Sri Lanka based on research by Wasantha Subasinghe (2015) where some big families occupied and rented small size housing. There was no separate room for parent and children. Arguments also often occurred because the head of the family did not perform his duties properly and the family became ignored and damaged. Based on study result on slum settlement, the category of community's income is relatively low. This low income affects everything such as education and health. There is a very 
strong relationship between economic prosperity and the enriching quality of life that is reflected in social indicator, health, literacy rates and environmental sustainability. These indicators serve as valuable inputs to develop appropriate policy initiatives to develop slum settlements. In the reality, the development of environment with progressive transformation of the economy and society's primary goal lies in the fulfillment of human needs and aspirations (Goswami and Manna, 2010; Hermon et al., 2018a; Hermon et al., $2018 \mathrm{~b}$.

People in slums live in miserable condition, lack of access to effective social and health services, poor drinking water and sanitation, so that they are prone to epidemics and vulnerable to development challenge. Their low socioeconomic status, low level of education and high fertility require special attention in public health, family planning and reproductive health programs. The rapid deployment of slum settlements leads to the dissemination of urban environmental degradation. Poverty still remains a main problem to environmental problems. Poverty is responsible for causing and resulting environmental degradation. Environmental problems and poverty are complex phenomena. Inequality could developed poverty so it was relied on natural resources and depleted natural resources because there was no other option to get another prospect, so that the environment was degraded. The slum is not only aroused and trapped in low income earning of community but also indicates that the institutional functions are low. Slum can be considered as low potential for government and private investment area, and provision of infrastructures is very difficult to reach slum area. The slum area had many uncertainties such as land ownership dispute and their own population had no desire to improve the quality of their settlement (Wasantha Subasinghe, 2015).

Therefore the government program is very important. One of these government programs is to destroy this slums by previously record and improve the existing slum area to become habitable housing. But from writer observation, the government only improves the building but not comply with health standard of the house itself because sanitation is still miserable in beach area of Labuhan Haji housing. It can be seen from a lot of mud and pool of water in front of the house. Government should identify ways to equitably distribute infrastructure facilities and social services. The government should provide health services, educational facilities, fire management and waste management (Arvind et al., 2006).

This government policy is analyzed by using Expert Choice application. Scoring is used in the questionnaire and Expert Choice application compares between criteria and among alternatives that assessed. Assessment is intended to compare the value or character of choice based on each criterion. For example on criterion 1 , between option 1 and option 2, option 1 is more important, then between option 1 and option 3 , option 3 is more important and so on until all options are compared one by one (in pairs). The result of the assessment is the value/weight that characterized each alternative. From 3 criteria, it will be compared between criterions based on the importance such as assessment table of importance below. Result shows there is still many slum areas in Nusa Tenggara Barat Province such as in area of Labuhan Haji, Kura-Kura Beach, and Sambelia District. The slum is highest in Labuhan Haji Beach area.

Table 1. Rating Score of Interest Score

\begin{tabular}{cl}
\hline Score Value & \multicolumn{1}{c}{ Information } \\
\hline 1 & One criterion with each other is just as important \\
3 & One criterion is slightly more important (somewhat stronger) than other Criteria. \\
4 & One criterion is more important (stronger in importance) than other criteria \\
5 & One criterion is very important compared to other criteria \\
& Criteria are one extreme of importance compared to other criteria 2, 4, 6, 8 Middle values between two \\
\end{tabular}

Based on interview result it also found that provincial government of Nusa Tenggara Barat has implemented program that is improving infeasible housing in some slum areas. Interview result with experts obtained that there are some policies that can be taken include forced eviction, home improvement with government funds, providing bank loans to improve housing. Provision of cheap homes or flats. Opening job openings to improve their lives. This government program is very important because housing is one of basic human needs, so the fulfillment of housing is a priority that cannot be deferred. Infeasible housing will bring diseases and can cause new problems. 


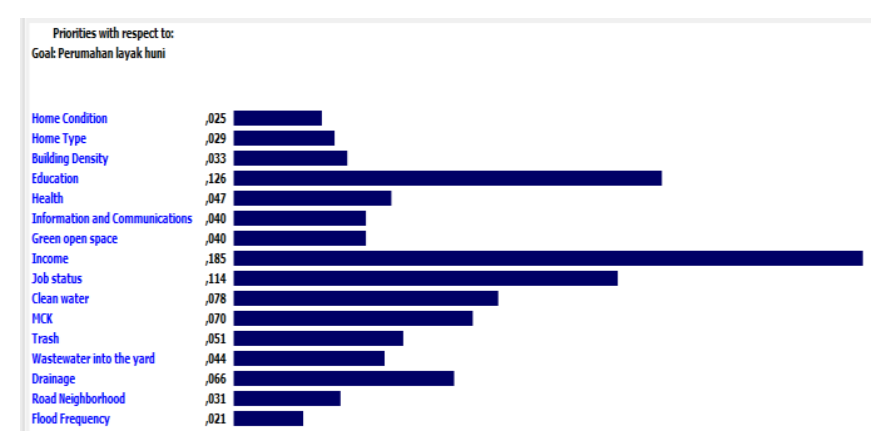

Figure 2. Priority results using AHP

Singapore Bank opened financing in 1960 used to finance the construction of public housing and it was allowed residents who lived in slums to buy housing units at subsidized level. Matsuyama (2005); Bowles, et al., (2006) explained that poverty was mostly found in rural area. The nature of slum-residents was difficult to be directed to improve the standard of marginal housing investment (Golgher, 2012).

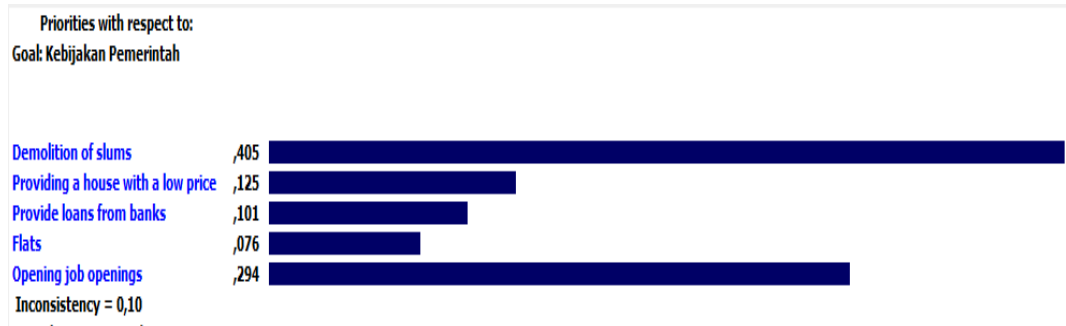

Figure 3. The Priorities of Slum Housing Policies

\section{Conclusion}

Based on discussion results, it is concluded that in Nusa Tenggara Barat there is slum areas such as in Labuhan Haji tourist area, Kura-Kura beach area and Sambelia district. The highest slum area based on research is Labuhan Haji area. The cause of this slum is low income. Community income is low and relatively low education in slum areas. Based on study results, it is obtained that the main priority in policy making is dismantling slum areas. The second priority is to provide jobs. Furthermore, to providing housing with low price and to provide loan from the bank for house renovation and the last option is to build flats can be other alternatives to improve slum areas.

\section{References}

Arvind V., S. Sanghamitra and T. Suchitra. (2012). Governance in the Provision of Public Goods in South Asia. Published: Indian Council for Research on International Economic Relations.Core-6A, 4th Floor, India Habitat Center Lodi Road, New Delhi-110 003.

Statistic Central Agency of East Lombok Regency Year 2015.

Bowles, S., S. N. Durlauf, and K. Hoff. (2006). Poverty Traps Princeton University Press

Dafe, F. (2009). No Business like Slum Business? The Political Economy of Continued Existence of Slums: A Case Study of Nairobi. Published: Development Studies Institute London School of Economics and Political Science, Houghten Street, London, WC2A 2AE UK, WPS No. 09-98. Directorate of Housing of East Lombok Regency. 
Goswami, S. (2012). Health and Child Development Paradox: Findings from Raipur Slums. Global Journal of Human Social Science Sociology, Economics \& Political Science, Volume 12 Issue 14 Version 1.0 Year 2012, USA.

Goswami, S and S. Manna. (2010). Social Aspects of Environment: A Study of Slums of Raipurcity Manand Life, January-June Vol-36 1 \& 2, Bidisha, India.

Goswami, S and S. Manna (2013). Urban Poor Living in Slums: a Case Study of Raipur City in India. "Global Publisher: Global Journals Inc. (USA) Online ISSN: 2249-460x.

Hermon, D. (2009). Dinamika Permukiman dan Arahan Kebijakan Pengembangan Permukiman pada Kawasan Longsor di Kota Padang. Disertasi. IPB Bogor

Hermon, D. (2012a). Dinamika Cadangan Karbon berdasarkan Perubahan Tutupan Lahan menjadi Lahan Permukiman di Kota Padang. Forum Geografi. Vol. 26. No. 1: 45-52

Hermon, D. (2012b). Mitigasi Bencana Hidrometeorologi: Banjir, Longsor, Degradasi Lahan, Ekologi, Kekeringan, dan Puting Beliung. UNP Press.

Hermon, D. (2014a). Impact of Land Cover Change on Climate Change Trend in Padang, Indonesia. Indonesia Journal of Geography. Vol. 46. No. 2: 138-142.

Hermon, D. (2014b). Geografi Bencana Alam. Radjawali Press.

Hermon, D. (2015). Estimate of Changes in Carbon Stocks on Land Cover Change in the Leuser Ecosystem Area. Forum Geografi. Indonesia Journal of Spatial and Regional Analysis. Vol. 29. Issue 2: 187-196.

Hermon, D. (2016a). The Changes of Carbon Stocks and $\mathrm{CO}_{2}$ Emission as The Result of Land Cover Change for Tin Mining and Settlement in Belitung Island Indonesia. Journal of Geography and Earth Sciences. Vol. 4: 17-30.

Hermon, D. (2016b). The Changes of Carbon Stocks and $\mathrm{CO}_{2}$ Emission as the Result of Land Cover Change for Tin Mining and Settlement in Belitung Island, Indonesia. Journal of Geography and Earth Science. Vol. 4. No. 1: 17-30.

Hermon, D., P. Iskarni., O. Oktorie., and R. Wilis. (2017). The Model of Land Cover Change into Settlement Area and Tin Mining and its Affecting Factors in Belitung Island, Indonesia. Journal of Environment and Earth Science. Vo;. 7. No. 6: 32-39.

Hermon, D. (2017). Climate Change Mitigation. Rajawali Pers (Radjagrafindo). Jakarta.

Hermon, D., A. Putra., and O. Oktorie. (2018a). Suitability Evaluation of Space Utilization Based on Enviromental Sustainability at The Coastal Area of Bungus Bay in Padang City, Indonesia. Vol. 14, Issu 41: 193-202.

Hermon, D., Ganefri., A. Putra., and O. Oktorie. (2018b). The Model of Mangrove Land Cover Change for the Estimation of Blue Carbon Stock Change in Belitung Island-Indonesia. International Journal of Applied Environmental Sciences. Vol. 13. Number 2: 191-202.

Matsuyama, K. (2005). Poverty Traps. In The New Palgrave Dictionary of Economics, 2nd Edition, edited by L. Blume and S. Durlauf. Palgrave Macmillan.

UN-HABITAT. (2002). Expert Group Meeting on Slum Indicators: Secure Tenure, Slums and Global Sample of Cities. UN-HABITAT. Nairobi.

Verma, G.D. (2002). Slumming India: A Chronicle of Slums and Their Savior, Penguin Books India.

Dance, E., I. Brown, and W. Chikagbom. (2015). Assessment of The Location and Availabilty of Public Facilities and Services In Port Harcourt Metropolis In Rivers State, Nigeria. International Journal of Scientific \& Technology Research Volume 4, ISSN 2277-8616

Subasinghe, W. (2015). Quality of Life Study on Slum Dwellers (With Special Reference to Sri Lanka International Journal of Scientific Research and Innovative Technology Vol. 2 No. 3

World Bank. (2009). The World Development Report 2009: Reshaping Economic Geography. Washington DC: The World Bank

Zhang, J. (2013). The issues facing the sustainable development of rural tourism and the path selection. Asian Agricultural Research. 